\title{
Formalin-Fixed Paraffin-Embedded B-Cell (CD20) Slide
}

National Cancer Institute

\section{Source}

National Cancer Institute. Formalin-Fixed Paraffin-Embedded B-Cell (CD20) Slide. NCI

Thesaurus. Code C125610.

A biospecimen consisting of formalin-fixed, paraffin embedded CD20-positive B-cells

affixed to a slide for light microscopy 